\title{
EXTENSION OF THE LIMITS OF CELLULAR PATHOLOGY : THE ROLE OF ENZYME HISTOCHEMISTRY
}

\author{
BY \\ A. G. EVERSON PEARSE \\ From the Postgraduate Medical School of London
}

"If we would serve Science we must extend her limits, not only as far as our own knowledge is concerned, but in the estimation of others."R. Virchow (1858).

"Cytology cannot be content to go on indefinitely finding new visible parts of the cell ... what it needs is to discover methods that will describe the organization of cellular events. . . ."-J. Z. Young (1956).

"New methods must be invented that will be sensitive enough to detect early functional changes."-G. R. Cameron and S. Muzaffar Hasan (1958).

My thesis is a simple one, and the three quotations which I have used, a selection from many which express the same opinions, illuminate what I have to say with a commendable economy of words.

The limits of cellular pathology, drawn up by Virchow 100 years ago, have been pushed forward in precisely the way that he suggested, by the application of histological techniques. At that time cellular pathology was not truly cellular but histological rather than cytological. Few pathologists are sanguine enough to: foresee further extension of pathology by these same histological methods, and it is clear that if advances are to be made in our knowledge of the mechanisms of pathological processes then new methods must be invented which will "describe the organization of cellular events" and which "will be sensitive enough to detect early functional changes."

Although Virchow was content to state that permanent advances in medicine were made solely by "discoveries concerning the structure of the body," the rise of biochemistry, in particular, has made it clear that analysis of structure without function is relatively barren. Histochemistry is concerned particularly in the correlation of structure with function.

We cannot be satisfied, says J. Z. Young, with identifying the new parts of the cell even by histochemical methods, and it must be admitted that information derived from the application of methods of analytical histochemistry is in most cases of limited value. It is to the newer techniques of functional histochemistry that we must look for help, and it is these alone which can transform descriptive analytical histopathology into a new science of functional cytopathology. This thesis I shall try to develop briefly, and I shall illustrate it, for the sake of simplicity, solely with examples from the field of enzyme histochemistry. Before doing this, however, it may be expedient to give details of the present status of that youngest division of the relatively old science of histochemistry.

If we except the few historical methods for indophenol (cytochrome) oxidase, peroxidase, and the still current method for DOPA-oxidase, which were in existence in the early years of the century, enzyme histochemistry can be considered to date from 1939 when George Gomori first described his method for alkaline phosphatase. By 1953 histochemical methods had been evolved for the demonstration of 18 different enzymes. Most of these belonged to the hydrolytic group and the majority were either carboxylic acid esterases or phosphatases. To-day the figure stands at 45 .

This is admittedly not very imposing when con- 3 sidered against the grand total of some 700 응 recorded enzymes (Dixon and Webb, 1958), but the distribution of these 45 methods among the main enzyme divisions is now much more even than it was only a few years ago. This is chiefly or due to the development of methods for hydrogen $N$ transferring enzymes, particularly the dehydro- N genases and diaphorases.

\section{Applied Enzyme Histochemistry}

A considerable amount of work has been carried out by the application of histochemical enzyme techniques to problems in the field of cellular pathology. Often the techniques them- 
selves have been criticized for lack of specificity and sensitivity and for inaccuracy in localization. Many of them clearly need improvement on this account, but until such time as better methods are developed there is much to be said for the employment of existing methods if these can be shown to provide useful information. Thus, although the degree of localization provided by the standard techniques for alkaline phosphatase is less than one would desire, Novikoff (1955) remarks that it is difficult to see how the distribution of this enzyme within organs could have been studied without a staining method. Precisely the same may be said for other enzyme systems, but the mapping of these, however attractive and important it may be to the pure histochemist, has little appeal to the pathologist who wants to know how and why different processes occur as well as where and when.

There are, nevertheless, a number of indications for the use of histochemical enzyme techniques in pathology, and a few examples may be cited to illustrate some of the facets of their use.

\section{General Enzyme Histochemistry}

In spite of the fact that a reasonable explanation for the mode of action of the enzyme is seldom forthcoming, the alkaline phosphatase method continues to be one of the most popular methods for application to pathology and to the other basic sciences. A histochemical enzyme method may be useful, even if the mechanism of action of the enzyme is not understood, since it can act as a sensitive indicator of functional changes. Histologists have long sought some indication of the activity of the adrenal cortex other than simple fat staining. Recently, Allen and Slater (1956) have shown that the level of alkaline phosphatase in the connective tissue and blood vessels of the mouse adrenal'cortex rises after stimulation of the gland with A.C.T.H. Similarly, Clayton and Hammant (1957) have observed an overall diminution of alkaline phosphatase, in the cells of the guinea-pig adrenal cortex after A.C.T.H. In human adrenal cortical tumours those regarded as clinically active are found to consist of cells having little or no alkaline phosphatase, with an intensely active stroma and blood vessel walls. Thus the results of a simple enzyme technique may be used to evaluate activity in respect of corticosteroid production.

While a raised level of alkaline phosphatase in a barrier tissue such as a blood vessel wall usually signifies that the transmitting function of the barrier is increased, no such interpretation can be put upon changes in acid phosphatase levels. Several other types of activity, however, have been shown to be accompanied by a rise in the level of this enzyme. It has been shown to occur, for instance, in active phagocytosis (Grogg and Pearse, 1952) and in cytolysis (Green and Verney, 1956). A fall in the level has been found in most types of prostatic tumour (Woodard, 1952), and this finding is common enough in respect of many enzyme systems in many different kinds of tumour for it to have almost the force of a general law. That is to say, an enzyme found in large amounts in the normal parent cell of a tumour is likely to be present in reduced amounts in its malignant offspring. The main exceptions to this rule concern the respiratory enzymes, but apparent exceptions may occur where an enzyme absent from the presumed parent cell is present in the cells of the tumour. The probable peptidase found in carcinoid tumours by Pearse and Pepler (1957) falls into this category.

On the whole, acid phosphatase is best used histochemically as an indicator either of increased mitochondrial activity or of actual mitochondrial damage, since a diffuse reaction in properly fixed tissues means that the enzyme has escaped from its normal environment. This is probably the significance of the increase shown by Pearse and Macpherson (1958) in the kidney of the potassiumdeficient rat.

Pathological applications of the standard methods for acetylcholinesterases and pseudocholinesterases have been limited in number and restricted practically to the skin and to the central nervous system. Glial cells, and particularly the fibrous astrocytes, have been reported to contain a strong pseudocholinesterase (Koelle, 1954; Cavanagh, Thompson, and Webster, 1954), but Pepler and Pearse (1957) were unable to show this in human astrocytes or in astrocytomas. Both of the standard histochemical methods for acetylcholinesterases are sensitive, specific, and reliable, and their application to neuropathological problems has already produced useful results.

Among the many methods for glycosidases, that for $\beta$-glucuronidase has been most often applied to pathological problems. Recent improvements in one of the standard methods by Fishman and Baker (1956) should encourage its application in the fields of endocrinology and neoplasia. Once again, however, the results may have to be interpreted in the absence of knowledge as to the exact part played by the enzyme. According to Monis and Rutenberg (1956), the demonstration of $\beta$ glucuronidase activity may be useful for the 
differentiation of epithelial and mesodermal tumours, since the latter do not possess the enzyme.

Diagnostic uses of enzyme histochemistry, as applied to pathological histology, are at present not numerous. This is hardly surprising, however, in view of the short period during which most of the applicable methods have been in existence. Further developments can only take place when the methods become more or less routine ones in histopathological laboratories. For this purpose the training of histochemical technicians is essential.

Another group of enzymes which has recently been brought into the histochemical orbit is the intracellular peptidases, particularly leucine aminopeptidase (Burstone and Folk, 1956 ; Nachlas, Crawford, and Seligman, 1957). Interest has centred on the production of the enzyme by invading tumours (Burstone, 1956) and on the rich source of the enzyme found in the stroma of such tumours. Sylvén and Malmgren (1955), using biochemical methods, found that the peripheral portions of invasive tumours contained higher cathepsin and dipeptidase activities than the older, central areas, and Braun-Falco (1957) has suggested that the production of aminopeptidase may be connected with invasiveness.

The activity of leucine aminopeptidase in the production of parathyroid hormone has been considered by Pearse and Tremblay (1958), who have demonstrated a presumably direct relationship between the two. The uniform distribution of the enzyme in normal rat parathyroid gland is shown in Fig. 1. The specificity of the histochemical method for leucine aminopeptidase has not been proved, so that, although it is interesting to speculate that either the parathyroid hormone, or its carrier protein, may have a terminal leucyl group, this point cannot be settled by histochemical methods. It remains certain that aminopeptidase activity is directly related to the production of parathyroid hormone.

The non-specific esterase methods have been widely used in applied histochemistry, but there has unfortunately been little effort to distinguish the various types of esterase activity on the basis of findings and classifications recorded in the biochemical literature. It is possible, following the work of Holt (Holt, 1952 ; Holt and Withers, $1952,1958)$, to show with considerable accuracy and reasonably quantitatively the position in the cell of a number of non-specific esterases, using halogen-substituted indoxyl acetates as substrates. The evaluation of changes observed in the level

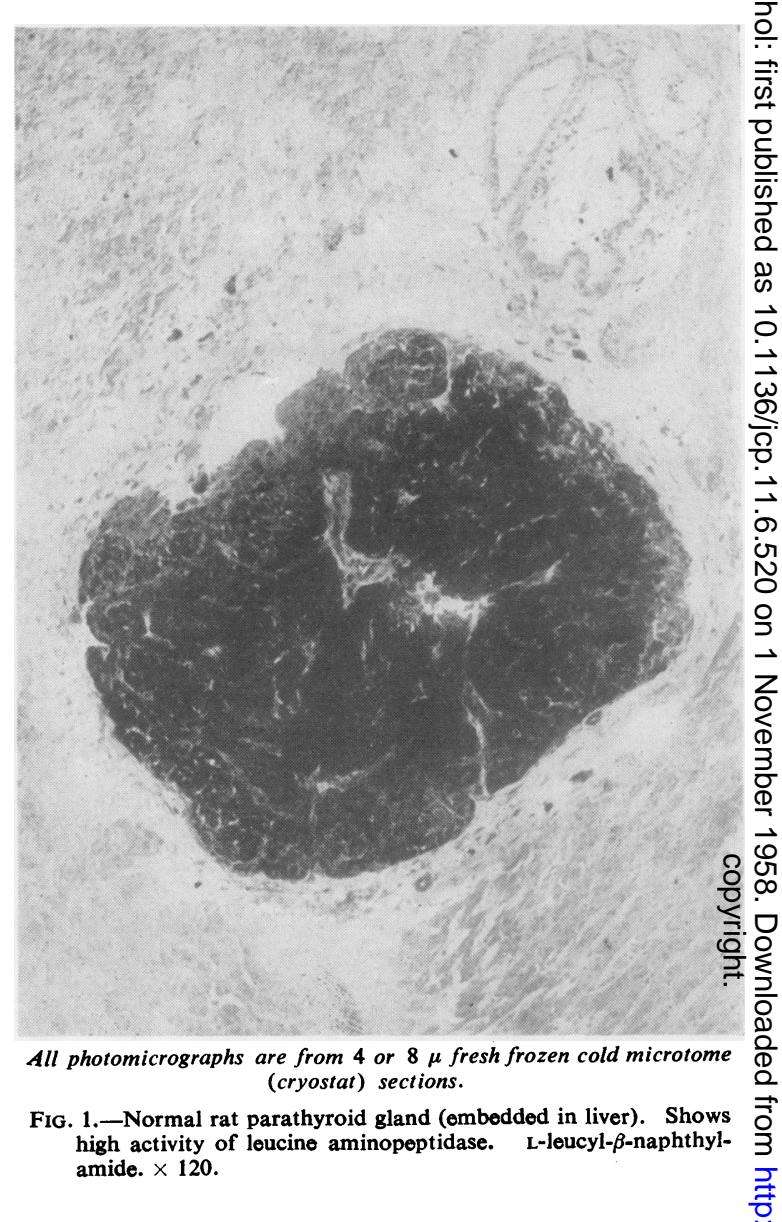

and distribution of these enzymes is difficult, however, since their exact function is poorly understood. The accurate degree of localization which these methods afford, however, and the possibility of determining small intracellular changes in function, make it essential to continue with their application on a much wider scale. Now that the substrates are more easily available former objections to the indoxyl methods must vanish.

It is unfortunately true of the majority of enzymes for which histochemical methods are available that their functional significance is $N$ obscure. When we come to the dehydrogenases and diaphorases, however, we observe a significant 0 difference. This is because biochemical knowledge of the function of these enzymes, within and outside the tricarboxylic acid cycle, is much more advanced than it is in the case of the other enzyme systems. Thus, if we can localize the dehydrogenases histochemically by methods in which the amount of colour developed is propor- 
tional to the rate of enzyme activity, we are in a position, as never before, to draw level with the biochemist in revealing the mechanisms by which the cell carries out its function in health and disease. We can then say something, at least, about the organization of events within the cell. I propose, therefore, to conclude this paper by considering briefly the current histochemical position in respect of the dehydrogenase systems, since I believe that the most promising developments in modern applied enzyme histochemistry are to be found in this field. Only one other field promises such advances. This is the division of immunohistology, based on the original fluorescent antibody methods of Coons and his associates (Coons, Creech, and Jones, 1941 ; Coons, Creech, Jones, and Berliner, 1942).

\section{Dehydrogenase Histochemistry}

Histochemical methods for the dehydrogenases are all derived from the original method of Seligman and Rutenburg (1951), which was derived in its turn from the successful use by Rutenburg, Gofstein, and Seligman (1950) of the so-called blue tetrazolium salt for the demonstration of dehydrogenase activity in extracts and homogenates. The principle depends on the acceptance of electrons by the colourless, soluble tetrazolium salt and its reduction to a coloured, insoluble, formazan dye.

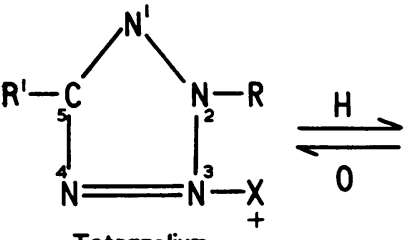

Tetrazolium

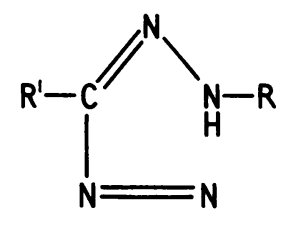

Formazan
The reaction is not reversible in biological systems, and the amount of formazan deposited can be related directly to the amount of enzyme activity (Defendi and Pearson, 1955; Glick and Nayyar, 1956). Developments which have taken place since 1951 have brought the dehydrogenase methods into the forefront of enzyme histochemistry. A series of papers by Farber and his associates (Farber, Sternberg, and Dunlap, 1956a and b ; Sternberg, Farber, and Dunlap, 1956 ; Farber and Louviere, 1956) set forth the authors' hypothesis that attempts to localize specific dehydrogenases by tetrazolium methods result only in the demonstration of one or other of the two pyridine-nucleotide-linked diaphorases. These flavoprotein enzymes transfer hydrogen from the substrate to the acceptor, in this case a dye or tetrazolium salt. The succinic dehydrogenase system forms an exception since it contains its own built-in flavoprotein and does not require the intervention of a diaphorase in transferring electrons from succinate to tetrazolium salts.

If Farber's hypothesis is true then the information which can be derived from the application of the tetrazolium methods will be severely limited in scope. If, on the other hand, the demonstration of specific dehydrogenases is shown to be possible the whole field is transformed. The significance of such a possibility in applied histochemistry can hardly be overestimated.

An outstanding drawback of all the tetrazolium methods in use up to 1957 was the crystalline nature of the formazan reaction product. The most commonly used tetrazolium salts (neotetrazolium, blue tetrazolium) both gave rise to two products, a red one soluble entirely in tissue lipids and a blue or purple one which formed thick needle-shaped crystals. It was thus impossible to obtain enzyme localization at a cytological level. These objections have recently been overcome, in two different ways, by the development of new tetrazolium salts.

The first of these, nitro-blue tetrazolium (NitroBT), was produced by Tsou, Cheng, Nachlas, and Seligman (1956) and applied by Nachlas, Tsou, de Souza, Cheng, and Seligman (1957) to the intracellular localization of succinic dehydrogenase. Nitro-BT is capable of accurate localization because its formazan has a strong binding capacity for protein (substantivity), and it is thus able neither to diffuse far from its site of origin nor to crystallize.

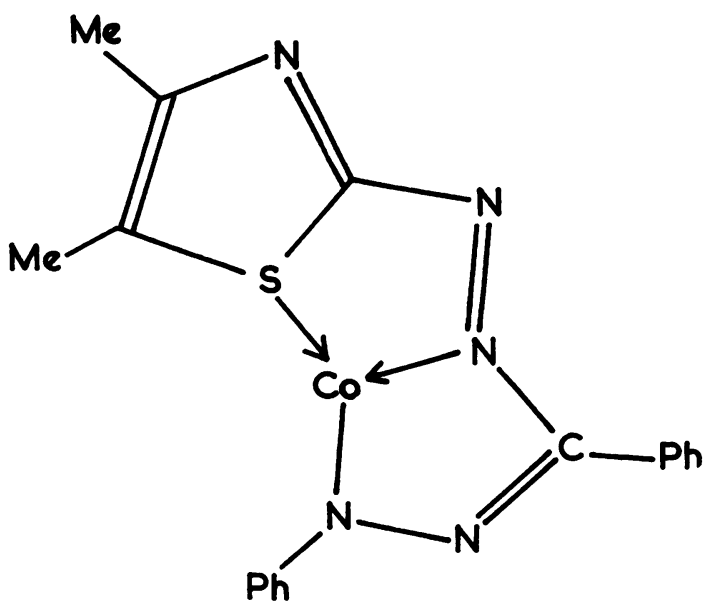

Cobalt formazan from 3-(4,5-dimethylthiazolyl-2-)2,5-diphenyl tetrazolium bromide (Beyer and Pyl, 1954). 
An entirely different principle is involved in the second method (Pearse, 1957) in which the formazan reduction product of a thiazol-substituted monotetrazolium salt (Beyer and Pyl, 1954) is captured in situ by chelation with a metal ion.

The usual metals are cobalt, nickel, and copper, in that order of preference. Both of the new methods are capable of localizing enzyme activity at the mitochondrial level (Figs. 2 and 3). In both cases the deposits of diformazan or cobaltmonoformazan are present in the mitochondria in the form of dots, measuring 0.25 to $0.35 \mu$ in diameter (Pearse and Scarpelli, 1958). These are much more easily seen with the cobalt-formazan technique. An average mitochondrion $3 \mu$ long may contain four formazan dots; the greatest number recorded in a single mitochondrion is six.

The view that tetrazolium methods can demonstrate only the two diaphorases and not the specific dehydrogenases with which they are linked has been shown to be erroneous by Nachlas, Walker, and Seligman (1958) and also by Hess, Scarpelli, and Pearse (1958). It is now possible, in fact, to demonstrate cytochemically the presence of nine of the pyridine-nucleotide-linked dehydrogenases, and these, together with succinic dehydrogenase, are shown in the diagram below by thick arrows. Stages indicated by thin arrows cannot at present be shown cytochemically.
Although homogenization and ultracentrifugation techniques have indicated that certain of the oxidative enzymes are intramitochondrial, others are consistently shown to be present mainly or entirely in other fractions. $\beta$-Hydroxybutyrate dehydrogenase, for example, is regarded as wholly mitochondrial, while the DPN-linked isocitrate dehydrogenase appears partly in the mitochondrial fraction and partly elsewhere. Glucose6-phosphate dehydrogenase is found exclusively in the supernatant. The newer cytochemical methods suggest that these three enzymes are all intramitochondrial (see Figs. 2, 4, and 5). The two diaphorases show a similar intramitochondrial pattern of localization (Fig. 6) and the biochemically recorded microsomal TPNH-diaphorase cannot be demonstrated cytochemically by the cobaltformazan technique (Scarpelli, Hess, and Pearse, 1958). Virchow, whose colostrum corpuscle was a "coherent globule" resulting from the fatty degeneration of an epithelial cell, would perhaps have enjoyed the macrophage from the breast of a lactating rat, shown in Fig. 4. This contains a "modern" colostrum corpuscle surrounded by short mitochondria typically rich in glucose-6phosphate dehydrogenase.

The ability to demonstrate effectively so many of the mechanisms of intracellular oxidation is obviously of great significance in relation to bio

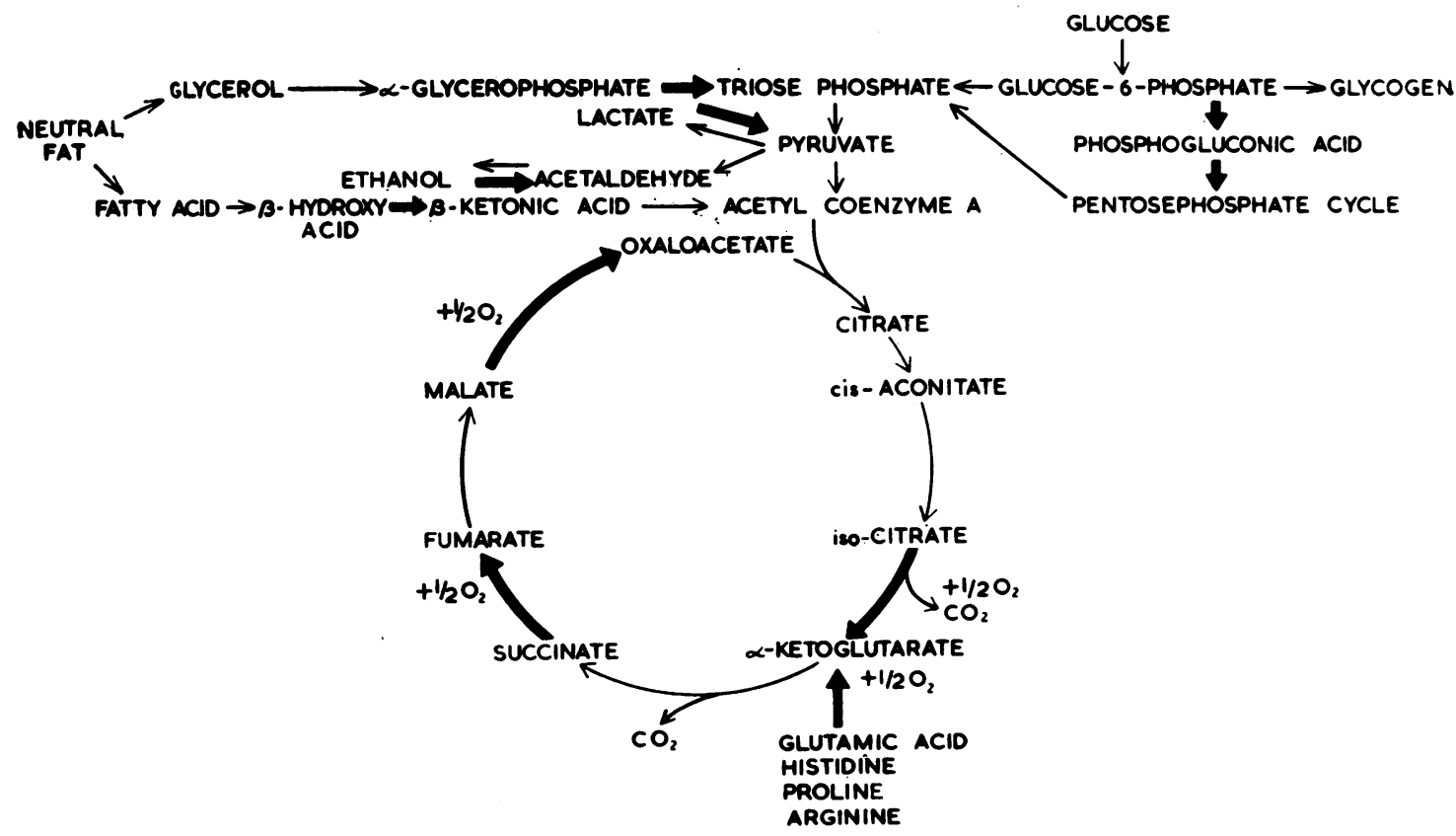




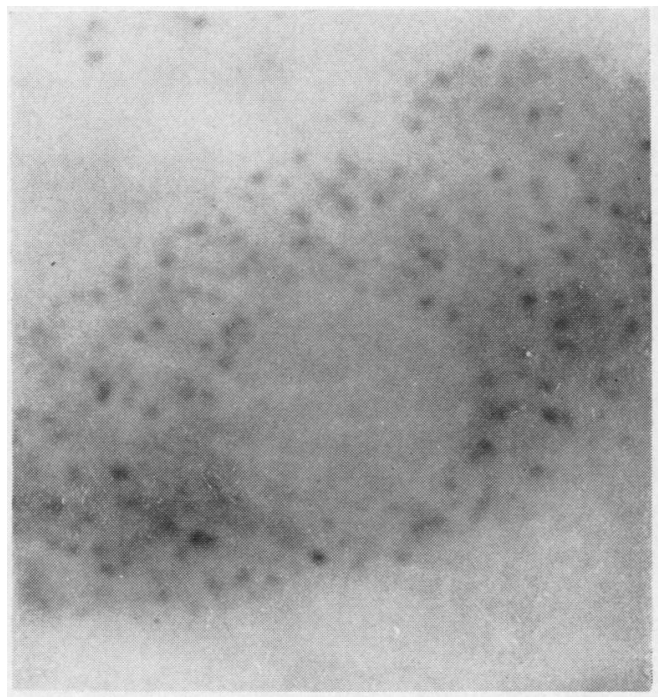

FIG. 2

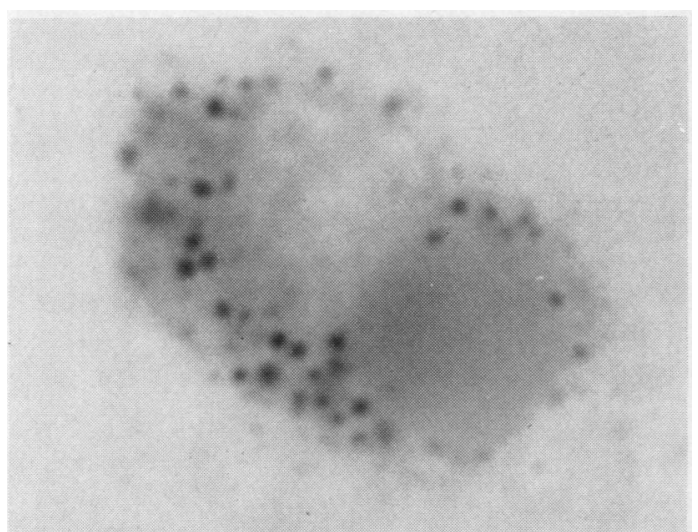

FIG. 4

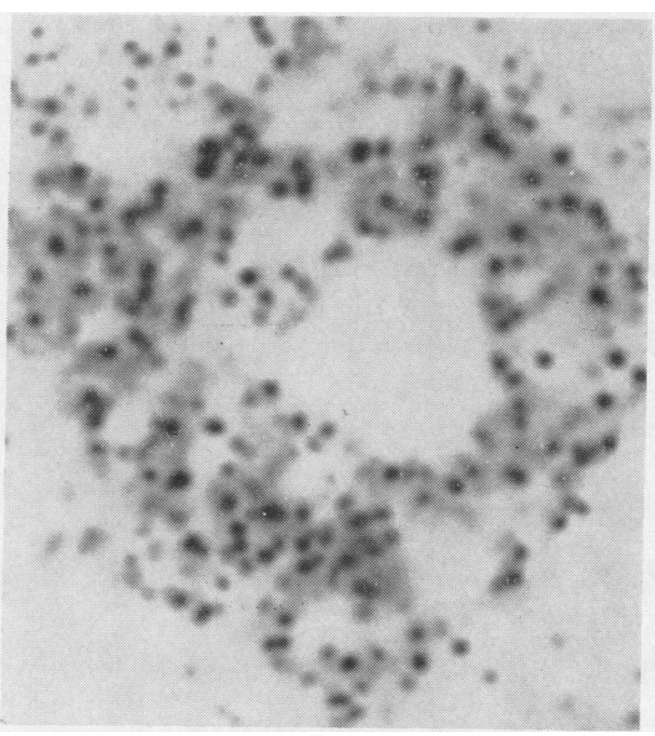

FIG. 6

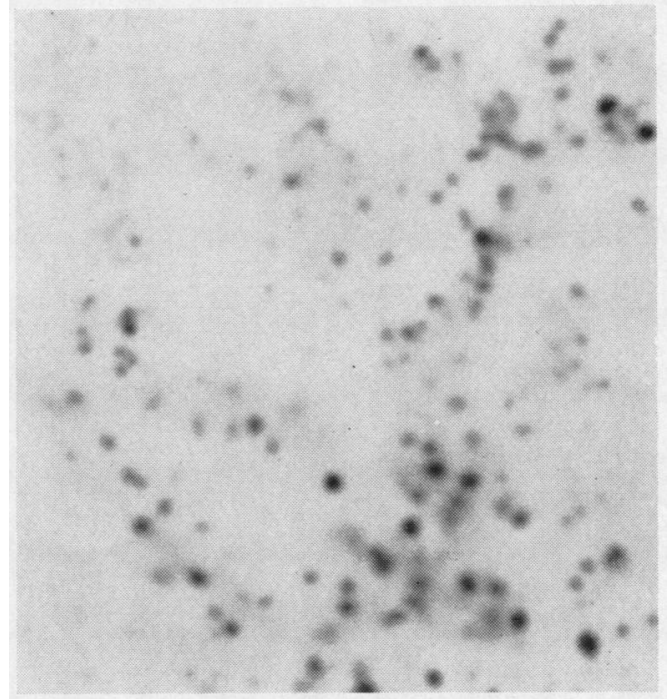

FIG. 3

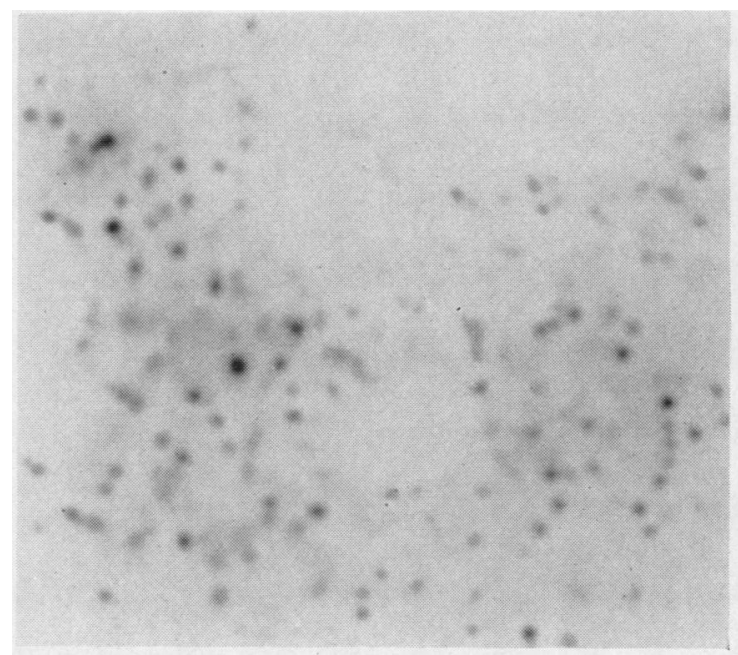

FIG. 5

FIG. 2.-Rat stomach. A single parietal cell. Shows distribution of DPN-linked isocitrate dehydrogenase activity. Nitro-BT. $\times 1,840$.

FIG. 3.-Rat kidney. Proximal convoluted tubule. Shows succinic dehydrogenase activity in the mitochondria. Cobalt-tetrazolium method. $\times 4,300$.

FIG. 4.-Rat breast (lactating). A single macrophage containing (lower right) a colostrum corpuscle. Shows glucose-6-phosphate dehydrogenase activity in the mitochondria. Cobalt-tetrazolium method. $\times 4,300$.

FIG. 5.-Rat kidney. Portions of a number of tubule cells. Shows $\beta$-hydroxybutyrate dehydrogenase activity. At lower right appears a single mitochondrion containing five formazan "dots." Cobalt-ietrazolium method. $\times 4,300$.

FIG. 6.-Rat salivary gland. DPNH-diaphorase activity in a single duct cell. Cobalt-tetrazolium method. $\times 4,300$. 


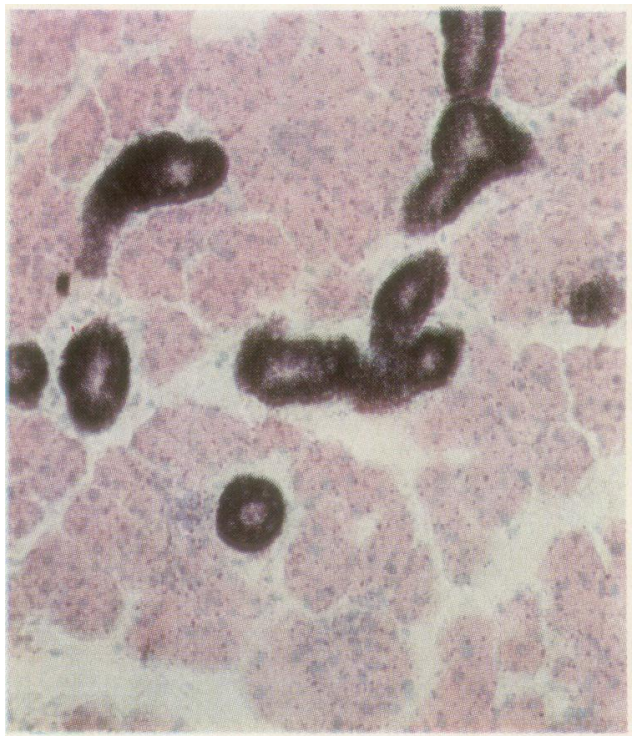

Plate IA.-Rat salivary gland. Shows high activity in duct lining cells but poor intracellular localization. Succinic dehydrogenase. Blue totrazolium, mothyl green, $\times 200$.

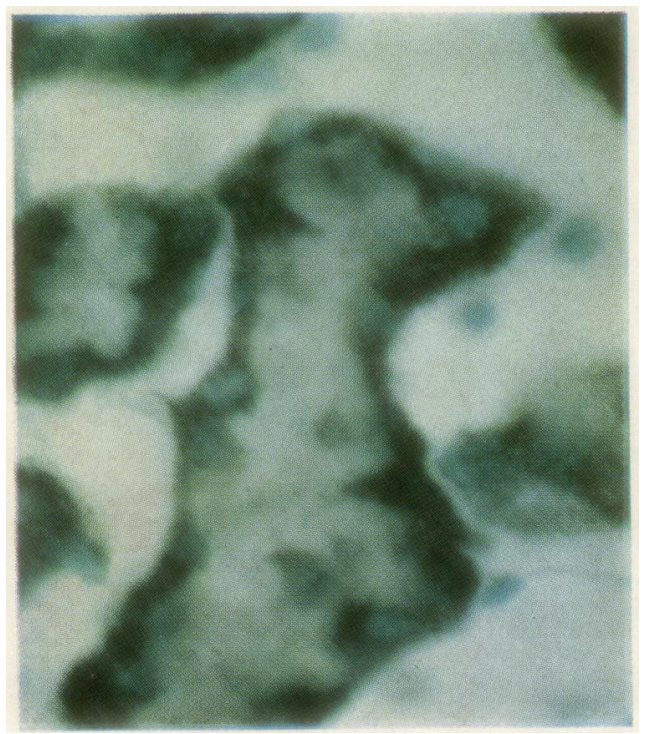

Plate IC.-Rat kidney. Distal convoluted tubules. Similarly improved localization provided by an efficient capture reaction. Succinic dehydrogenase. Cobalt-totrazolium, mothyl green, $\times 700$.

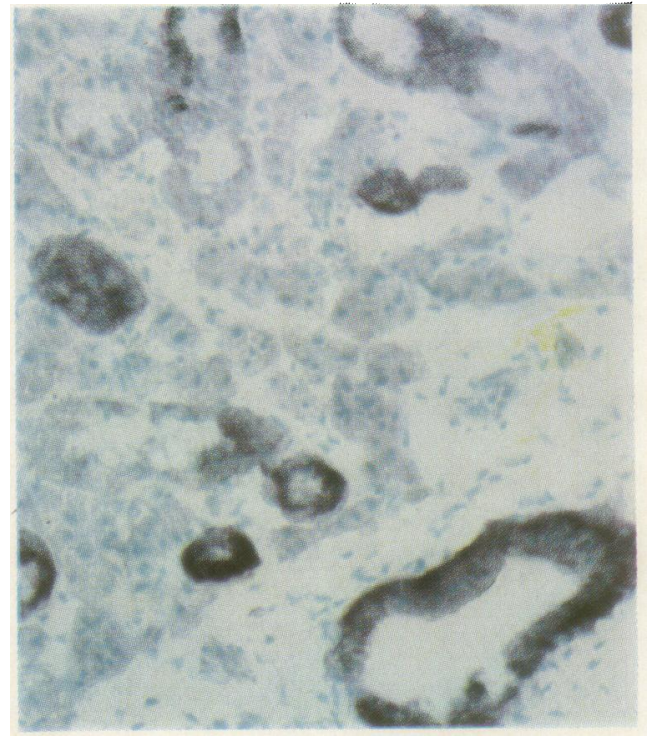

Plate IB.-Rat salivary gland. Shows great improvement in intra- $\overrightarrow{0}$ cellular localization afforded by the use of a tetrazolium salt $\vec{G}$ having a substantive formazan. Succinic dehydrogenase $\infty$ Nitro-BT, methyl grœen, $\times 200$.

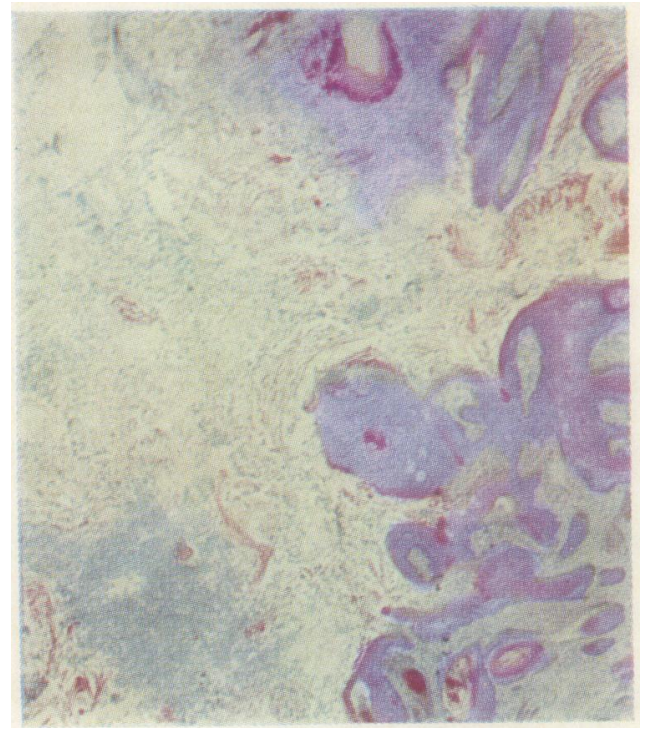

Plate ID.-Mouse cervix. Methylcholanthrene-inducod squamous coll carcinoma. Growing edge of the tumour. Solochrome cyanine RS. $\times 124$. 
logical and pathological problems. It becomes possible to follow small alterations in the level of the preferential oxidation pathway in single cells and to detect changes from one predominant pathway to another. This cannot be achieved by biochemical methods except in the case of homogeneous tissues. Even then, as Schneider (1956) has emphasized, the result is the average of the contribution of a number of different cell types, and of cells of a single type with widely differing enzyme contents. Speaking of the standard biochemical homogenization techniques, with which he and others have made so considerable a contribution to our knowledge of intracellular oxidations, Novikoff (1956) says, "It is well recognized that the activity of a given fraction obtained by differential centrifugation is an average figure." $\mathrm{He}$ goes further and says, "Even if it were possible to free the mitochondrial fraction, for example, of all contamination by

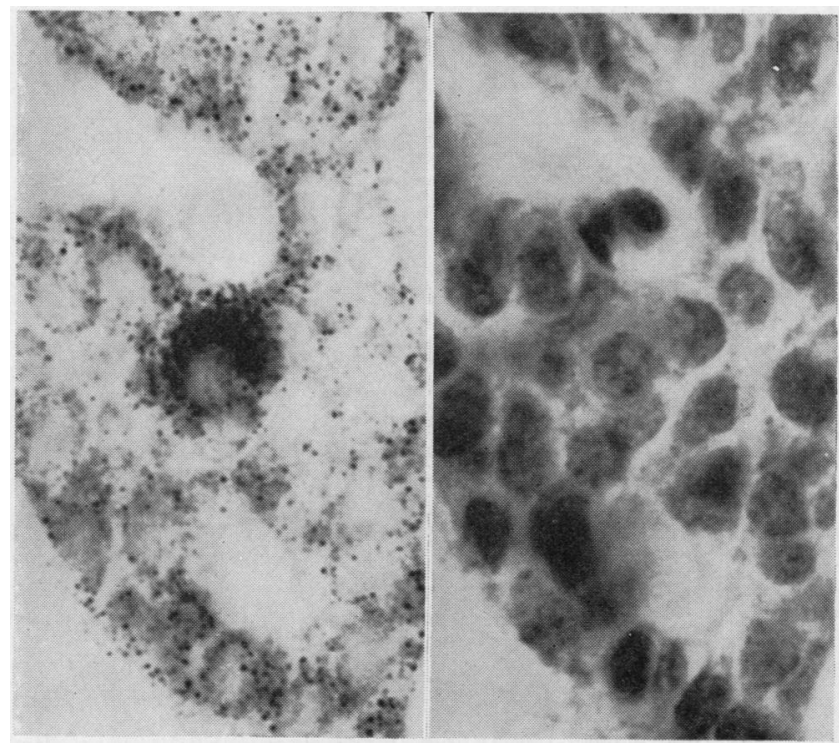

Fig. 7

FiG. 8

FIGs. 7 and 8.-Part of parathyroid gland of monkey (Macaca irus). Fig. 7 shows a high activity of DPNH-diaphorase in a single oxyphil cell. The same cell appears in Fig. 8, stained with haematoxylin and eosin. $\times 900$. ences existing among diverse mitochondria within a cell, and among different cell types, would still be merged into the average." "This limitation," he says, "is particularly troublesome when the organism is subjected to altered conditions which may shift the relative proportion of different mitochondria within a cell or of different cell types in the organ." Dehydrogenase cytochemistry is free from these limitations though subject to certain others. Absolute quantitation of enzyme activity, for instance, cannot at present be achieved. Nevertheless, the sensitivity of the histochemical methods is such that $\beta$-hydroxybutyrate activity can be demonstrated in the particles of KeilinHartree preparations although such activity is not detectable by the usual manometric (Warburg) methods.

Application of the newer histochemical methods for dehydrogenases and diaphorases has already shown clearly that the mitochondrial population is not homogeneous from cell to cell, or even within a single cell, and that this lack of homogeneity occurs not only with reference to content of specific enzymes but also with reference to physical states, such as the permeability of the mitochondrial membrane and the sensitivity of the organelle to environmental influences.

We can now show, therefore, not only the differences between one tissue and another and between one cell and another, but also between one mitochondrion and its neighbour.

\section{Applied Histochemistry of the Dehydrogenases and Diaphorases}

It is unlikely that biochemical studies on the DPN-linked dehydrogenases of the parathyroid gland have yet been carried out. If they have, they will have indicated a moderate level of activity little influenced by physiological changes in function. Studies on succinic dehydrogenase will show a similarly moderate and constant level of activity. Histochemical studies, on the other hand (Tremblay and Pearse, 1959), reveal that DPNH-diaphorase, and five of the histochemically demonstrable dehydrogenases which require this enzyme, are concentrated in the oxyphil cells. The latter are not present in the majority of species. In the monkey, however, they are well developed and the glands can be obtained in the fresh state necessary for the successful application of the methods. Figs. 7 and 8 show a single oxyphil cell, first with its content of intramitochondrial DPNH-diaphorase, and subsequently, after removal of the metal formazan, by staining with haematoxylin and eosin.

A similar concentration of DPNH-diaphorase is shown in Fig. 9, in a symplastic giant cell in a sarcoma produced experimentally in a mouse by 


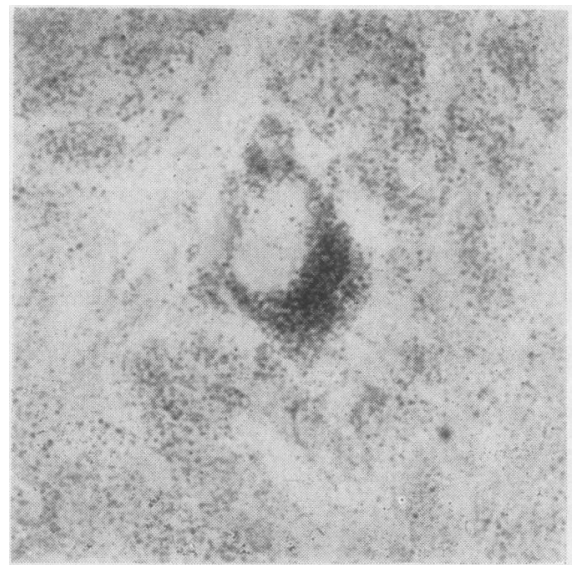

FIG. 9.-Mouse tissue. A methylcholanthrene-induced sarcoma. Shows a high activity of DPNH-diaphorase in a so-called symplastic giant cell. Low activity in the other tumour cells. Cobalttetrazolium method, carmalum. $\times 640$.

implantation of methylcholanthrene. In both cases it is tempting to assume that this intense enzyme activity is related to increased capacity for oxidation, and that this in its turn is related to the synthesis of products as yet unknown.

Histochemical studies have also shown that there is a special localization of 6-phosphogluconate dehydrogenase in the macula densa of the normal rat kidney (Nachlas et al., 1958), and this has been confirmed by Hess and Pearse (1959) in the case of this enzyme and also for glucose-6-phosphate dehydrogenase. In experimental hypertension in the rat, induced by means of a Goldblatt clamp, the clamped kidney shows no activity of glucose-6-phosphate dehydrogenase except in the macula densa and in the arterial and arteriolar walls. In the unclamped kidney the amount of enzyme in the macula densa falls to low levels. The appearance of the normal macula densa in the rat is shown in Fig. 10, where the activity of the glucose-6phosphate dehydrogenase in the mitochondria of the five or six cells concerned is evident. If biochemical studies were carried out a low level of enzyme activity would be recorded, and it is possible that in the early stages no difference could be shown between the clamped and unclamped kidneys. Hess and Pearse have shown that, as far as the macula is concerned, the level of glucose-6-phosphate dehydrogenase rises in the clamped kidney as the development of hypertension proceeds. Changes in the rabbit macula densa in hypertension were recorded by Goormaghtigh (1939), who described swelling and vacuolation of the cells (marked SI in the

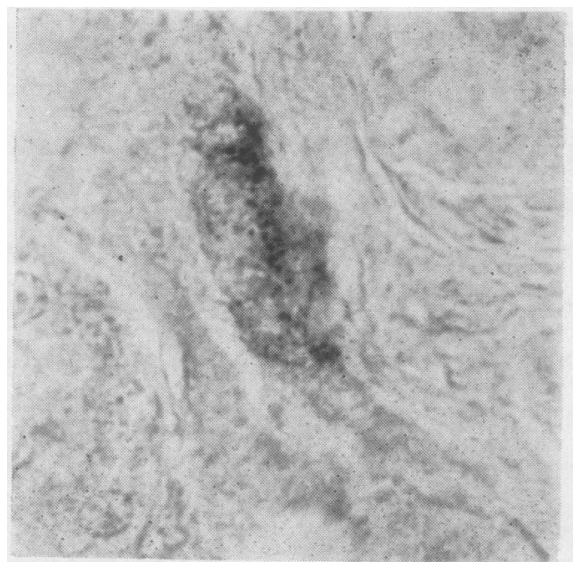

Fig. 10.-Rat kidney. Normal macula densa shows glucose-6phosphatase activity. Cobalt-tetrazolium method, carmalum. $\times 1,000$.

diagram below, which is reproduced from his paper), but no evidence of increased activity has hitherto been recorded. The juxtaglomerular apparatus (YG) is ultimately involved, in longstanding hypertension, in the general arteriolar increase in glucose-6-phosphate dehydrogenase.

\section{Further Examples in Applied Dehydrogenase Histochemistry}

The inhomogeneity of cells in a single type is well shown by reference to various types of tumours. Plate ID shows the advancing edge of a squamous carcinoma of the mouse cervix, pro-

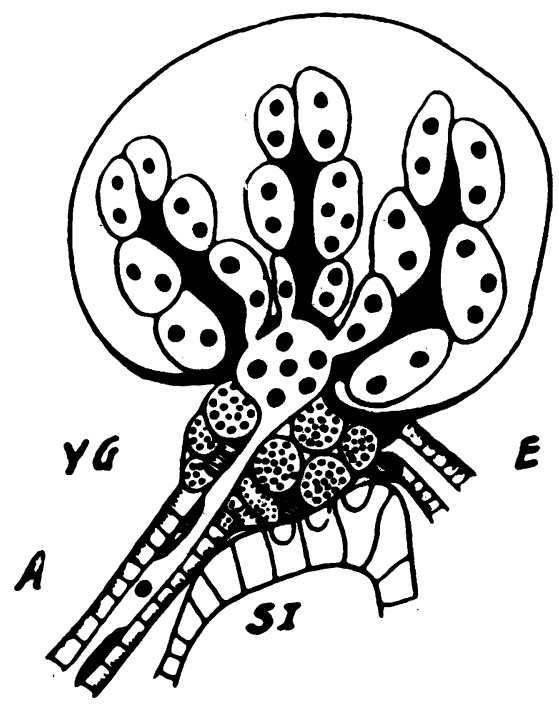




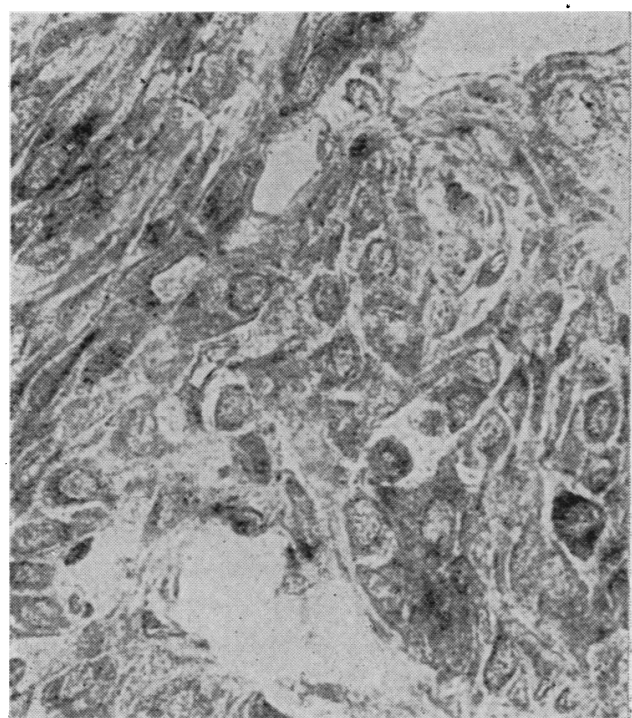

Fig. 11

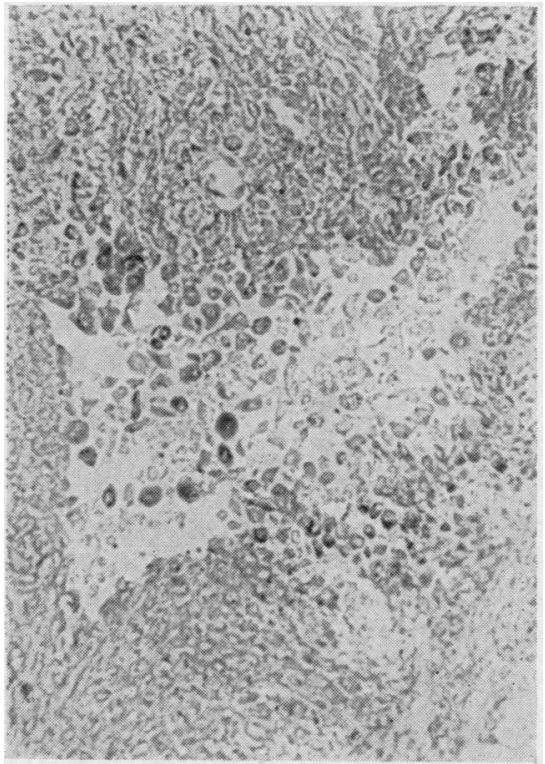

Fig. 13

FIG. 11.-As Plate ID. DPNH-diaphorase reaction. Shows wide variation in level of activity in healthy cells. Cobalttetrazolium mothod. $\times 490$.

Fig. 13.-As Fig. 12. Shows very high activity of glutamate dehydrogenase in cells which are about to keratinize. Nitro-BT. $\times 630$.

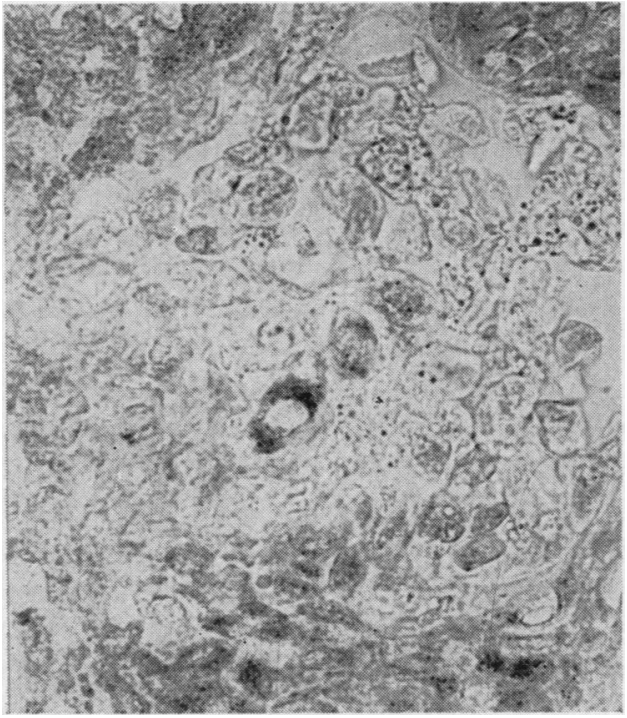

Fig. 12

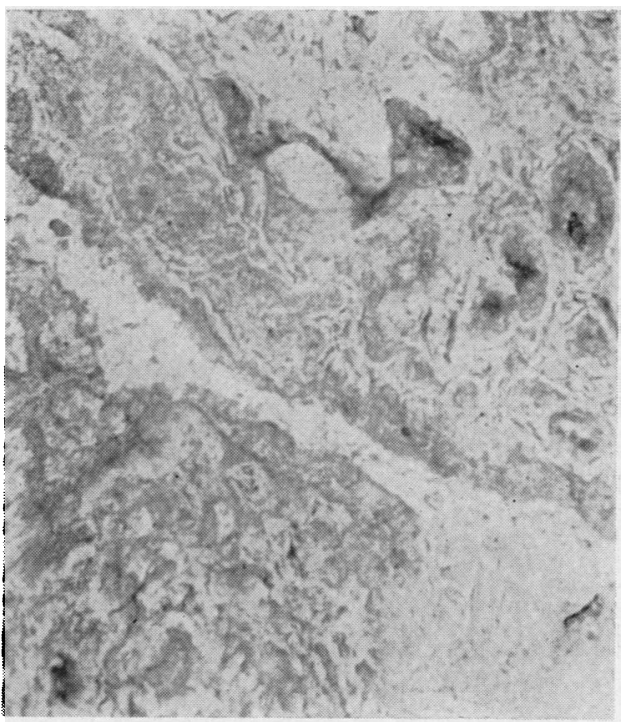

Fig. 14

FIG. 12.-As Fig. 11, but shows a region of keratinization. Low enzyme activity in most cells. Cobalt-tetrazolium method. $\times 475$.

Fig. 14.-As Plate ID. Growing edge of tumour. Shows high activity of glucoso-6-phosphato dehydrogenase in the advancing cells. Cobalt-tetrazolium mothod. $\times 630$. 
duced experimentally by implantation of methylcholanthrene (Scarpelli and von Haam, 1957), which has been stained in a conventional manner. In the next illustration (Fig. 11) a similar area has been shown to demonstrate the localization of DPNH-diaphorase in the mitochondria. Histologically all the cells present are healthy and viable, and without distinguishing features. The enzyme method shows, however, that some have little activity and others, such as the cell in the lower right-hand part of the picture, are intensely active. This difference in activity of DPNHdiaphorase is not unnaturally much greater in the keratinizing areas of the tumour (Fig. 12) where the fully keratinized cells contain little or no enzyme. There is an interesting change observable in cells which are just about to keratinize (Fig. 13), where a pronounced rise in glutamic dehydrogenase is seen. There is no parallel rise in any of the other dehydrogenases. An entirely different picture is seen in the growing edges of the tumour (Fig. 14). Here, there is a relatively enormous rise in glucose-6-phosphate dehydrogenase activity and this is closely followed by a rise in ribonucleic acid levels within the cells.

Clearly these results are significant and we have to ask ourselves, or the biochemists, what they mean. In Table I the predominant oxidative mechanism associated with a given enzyme system is recorded.

TABLE I

SUGGESTED SIGNIFICANCE OF DEHYDROGENASE ACTIVITIES

\begin{tabular}{|c|c|c|c|c|}
\hline \multicolumn{3}{|c|}{ Substrate Utilized } & Co-enzyme & $\begin{array}{l}\text { Mechanism Involved or } \\
\text { Significance }\end{array}$ \\
\hline \multicolumn{2}{|c|}{$\begin{array}{l}\text { Succinate } \ldots \\
\beta \text {-OH butyrate }\end{array}$} & $\ldots$ & $\begin{array}{l}\text { None } \\
\text { Co I }\end{array}$ & $\begin{array}{l}\text { Citric acid cycle } \\
\text { Fatty acid oxidation } \rightarrow \text { active } \\
\text { acetyl synthesis }\end{array}$ \\
\hline Glutamate & . & $\cdots$ & Co I & $\begin{array}{l}\text { Synthesis or breakdown of } \\
\text { glutamate } \\
\text { Urea or creatine formation }\end{array}$ \\
\hline $\begin{array}{l}\text { Malate } \\
\text { Isocitrate }\end{array}$ & $\begin{array}{l}\cdots \\
\cdots\end{array}$ & $\cdots$ & $\begin{array}{l}\text { Co I } \\
\text { Co I or } \\
\text { Co II }\end{array}$ & $\left\{\begin{array}{l}\text { Citric acid cycle } \\
\alpha-\text {-Ketoglutarate } \\
\text { citric acid cycle }\end{array}\right.$ utilization \\
\hline \multicolumn{3}{|c|}{ Glucose-6-phosphate } & Co II & $\begin{array}{l}\text { Metabolism via oxidative (hex- } \\
\text { ose monophosphate) shunt } \\
\text { synthesis of }\left\{\begin{array}{c}\text { A.T.P. } \\
\text { Nucleotides }\end{array}\right.\end{array}$ \\
\hline \multicolumn{3}{|c|}{$\alpha$-Glycerophosphate } & $\begin{array}{l}\text { Co I } \\
\text { Co I }\end{array}$ & $\begin{array}{l}\text { Glycolysis (early stage) } \\
\text { Glycolysis }\end{array}$ \\
\hline Lactate & $\because$ & $\cdots$ & Co I & Glycolysis (later stage) \\
\hline DPNH & & . & Diaphorase & $\begin{array}{l}\text { Total activity of Co-I-linked } \\
\text { dehydrogenase systems } \\
\alpha \text {-Lipoic acid shunt }\end{array}$ \\
\hline TPNH & . & . & Diaphorase & $\begin{array}{l}\text { Total activity of Co-II-linked } \\
\text { dehydrogenase systems }\end{array}$ \\
\hline
\end{tabular}

Most of the information in the table is derived from biochemical studies and obviously requires amplification. Such amplification is beyond the scope of this article.

\section{Indications of the Physical State of Mitochondria}

The mitochondria fresh frozen sections are altered in some respects by the freezing and thawing involved. They can no longer carry out oxidative phosphorylation, for example. If steps are taken in histochemical practice to preserve the integrity of the mitochondria as far as possible, by avoiding heating or drying and by their protection during incubation with the use of hypertonic media ( $7.5 \%$ polyvinyl pyrrolidone), the appearances with the latest tetrazolium methods are those shown in Figs. 2-6. The mitochondria are still intact, as can readily be ascertained by inspection with the phase microscope. If for any reason a mitochondrion is damaged before incubation, so that the membrane is abnormally permeable, the first result is that the reaction rate increases and more formazan per unit time is deposited. The appearances of such mitochondria are recorded in the right-hand tubule of the kidney section shown in Fig. 15. The middle tubule contains essentially normal mitochondria. If the damage is so severe that the mitochondrial membranes are ruptured the appearances in the section approach those seen in the left-hand tubule in Fig. 15.

If an osmotic load is put upon the mitochondria, by pre-incubating the fresh frozen sections in hypotonic or otherwise harmful media, those which are abnormally sensitive are observed to respond sooner and more violently than the normal ones. We thus have a tool which is capable of showing very early changes in the physiological state of the mitochondria, and we can therefore indicate pathological changes in a variety of conditions a long time before any change can be seen by conventional methods.

In Fig. 16 is shown the TPNH-diaphorase reaction in the juxtamedullary tubules of the renal cortex of a rat maintained for 36 hours on a diet deficient in magnesium. Swollen (damaged) mitochondria, sometimes only one per cell, are visible. The renal tubules in other areas show absolutely no abnormality. The change is more easily seen at .higher magnification, as in Fig. 17 (succinic dehydrogenase) and more easily still in Fig. 18, which shows the same tissue pre-incubated for 30 minutes in a hypotonic medium. Such treatment produces no response from the normal mitochondria of these tubules (though it may from the more sensitive normal mitochondria of other organs such as the parietal cell of the rat stomach shown in Figs. 19 and 20). It is thus possible to calibrate every type of mitochondrion in every tissue and to apply to it just that load which will 
Fig. 15.-Rat kidney. Reaction of mitochondria to osmotic injury. This chance observation in a single section shows, left, disrupted mitochondria; right, swollen (damaged) mitochondria containing more formazan than the normal mitochondria of the central tubule. Succinic dehydrogenase. Cobalt-tetrazolium method. $\times 850$.

FIG. 16.-Rat kidney. Juxtamedullary region of the cortex. Three days $\mathrm{Mg}$ deficiency. Shows early change in mitochondria (swelling and increased reaction rate). TPNH-diaphorase. Cobalt-tetrazolium method. $\times 750$.

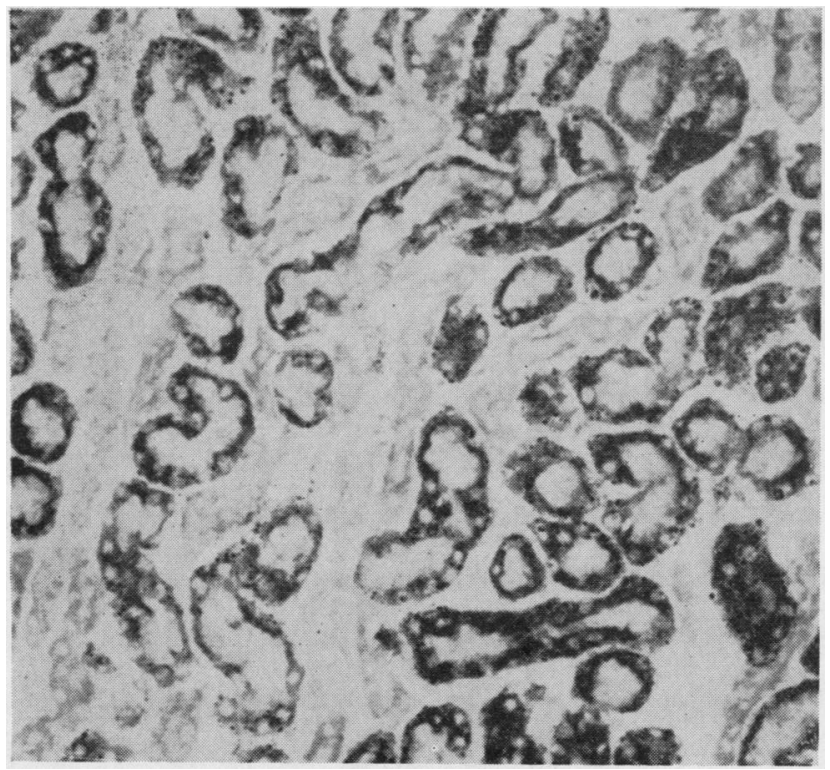

FIo. 16
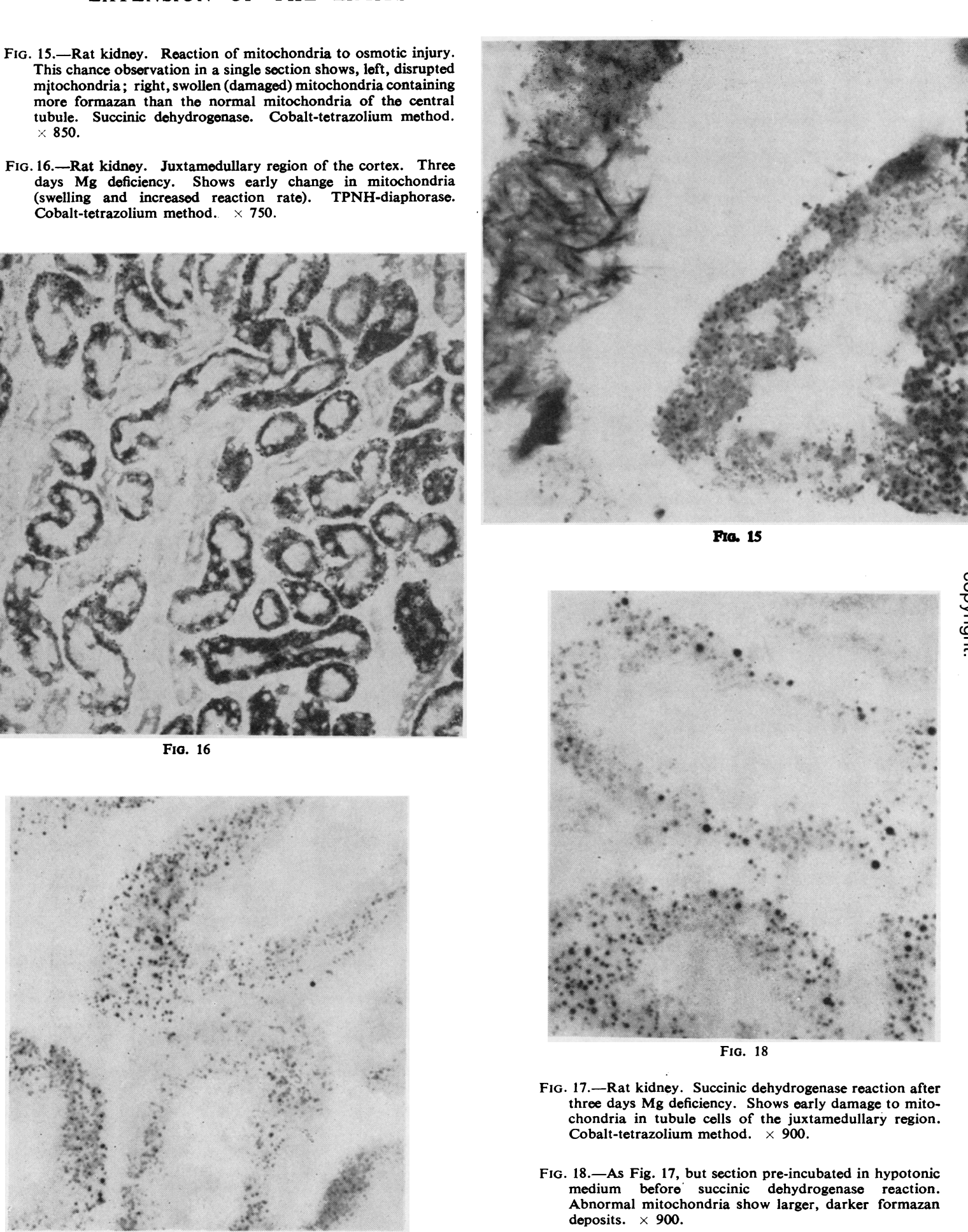

Fa. 15

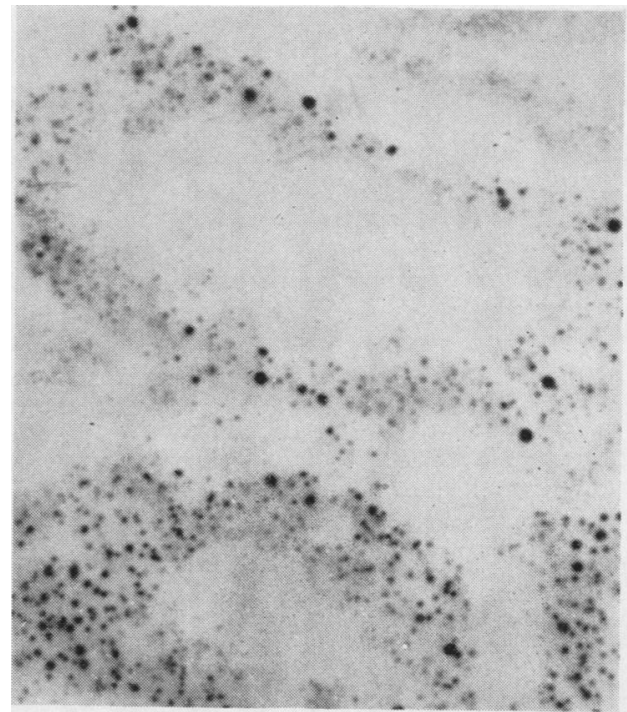

FIG. 18

Fig. 17.-Rat kidney. Succinic dehydrogenase reaction after three days $\mathrm{Mg}$ deficiency. Shows early damage to mitochondria in tubule cells of the juxtamedullary region. Cobalt-tetrazolium method. $\times 900$.

FIG. 18.-As Fig. 17, but section pre-incubated in hypotonic medium before succinic dehydrogenase reaction. Abnormal mitochondria show larger, darker formazan deposits. $\times 900$. 


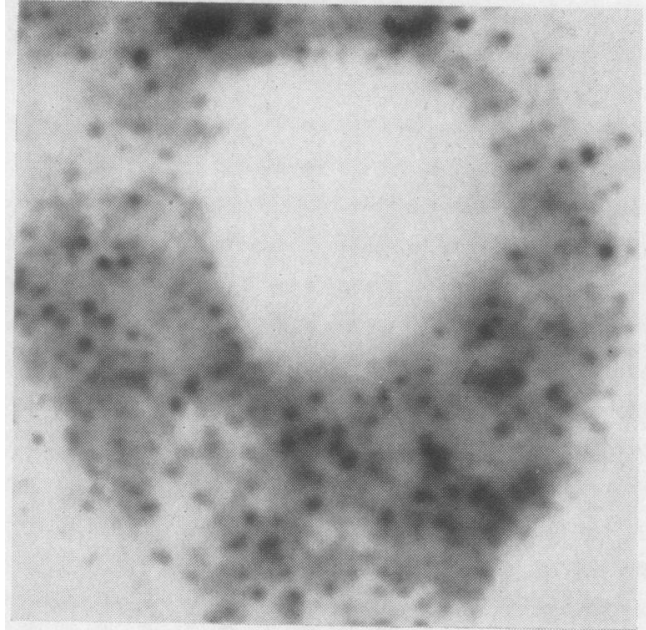

F10. 19

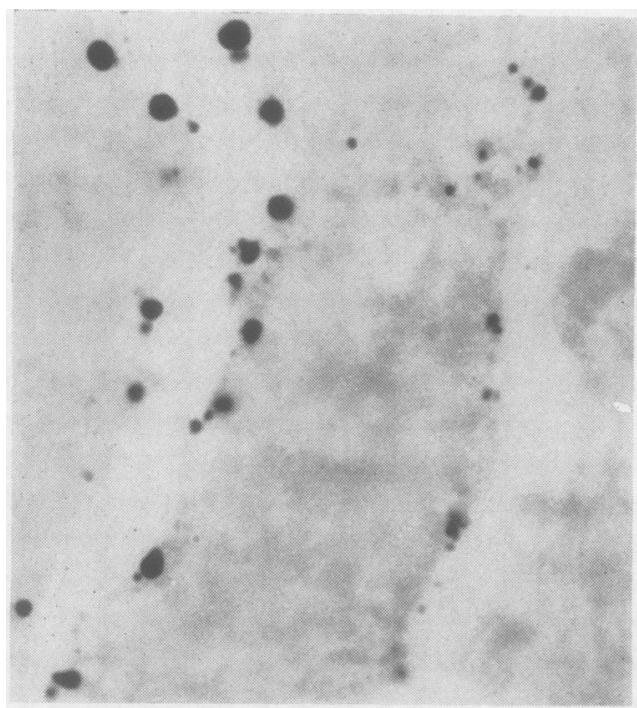

Fig. 21

FIg. 19.-Rat stomach. Parietal cell incubated for succinic dehydrogenase in a protective medium. Shows mitochondrial localization of enzyme. $\times \mathbf{4 , 4 5 0}$.

Fig. 21.-Rat kidney. Early stage of $\mathrm{Mg}$ deficiency (fifth day). Shows fatty degeneration. Oil red $0 . \times 900$.

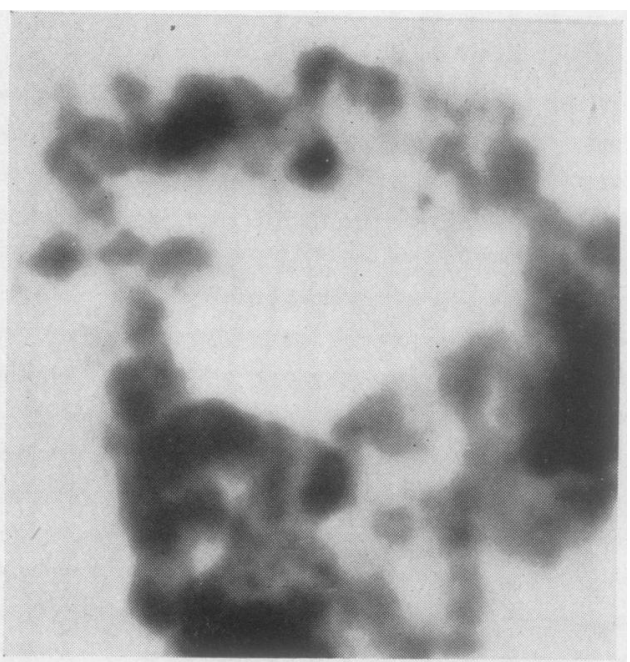

Fig. 20

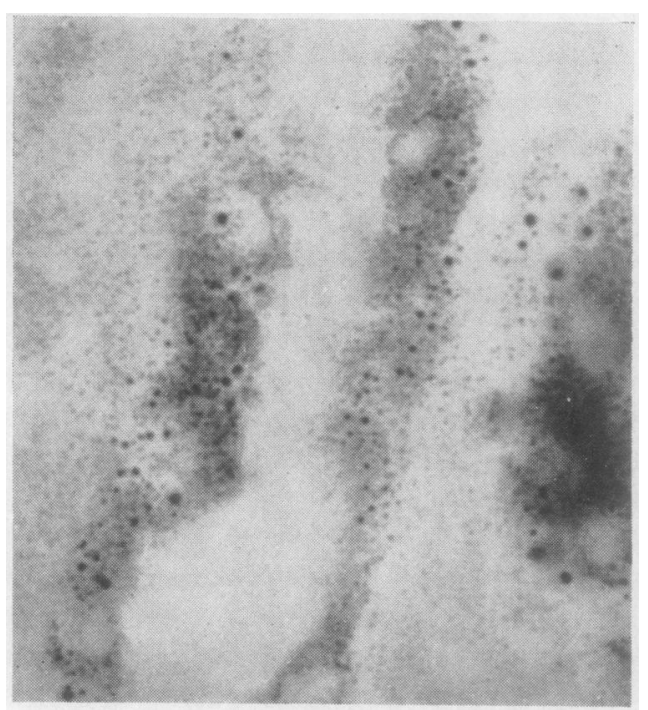

FIG. 22

FIG. 20.-As Fig. 19, but incubated in hypotonic medium. Individual mitochondria are entirely unrecognizable. 4,450 .

FIG. 22.-Rat kidney. Similar stage to Fig. 21. Shows close association of exrly stages of fatty degeneration (clear halos) with mitochondrial damage or swelling. DPNHdiaphorase. $\times 900$. 
reveal the earliest change in sensitivity (permeability) of the membrane. The implications of such a method in experimental pathology need little amplification.

The gross changes in the kidney of magnesium deficiency, which include intracellular and interstitial calcification, become visible by standard techniques after a period of about nine days. They occur in precisely the area delineated by "mitochondrial assay" a matter of hours after the start of the experiment. Biochemical changes are noted on the fifth or sixth day, when the serum magnesium figures fall to low values. The "blindness" of the usual histological techniques needs no further emphasis.

A similarly early appreciation of the pathological changes has been observed in every condition to which the methods of "mitochondrial assay" have been applied. In poisoning with diphtheria toxin, for example, changes are visible in the sarcosomes of the cardiac muscle two hours after injection of the toxin. This compares with the seven days of the usual techniques. In renal calcification, induced by single doses of vitamin $D$, changes are similarly visible in a few hours in the region of the kidney where ultimately (nine to 15 days) massive calcification occurs. It is possible, incidentally, using sensitive fluorescent techniques for calcium (Pearse, 1959), to detect the deposition of calcium in the interstitial tissues and in some of the cells of the renal tubules by the fifth day of the experiment. Starvation is another condition which induces changes in animal tissues and these can likewise be appreciated by "mitochondrial assay" after only a few hours' deprivation of food (in the case of the rat). It is interesting to note that the fatty degeneration, described and studied by Dible and Gerrard (1938), and by other workers (Fig. 21), appears to be closely connected with the swelling of damaged mitochondria. This is seen in Fig. 22, where the swollen mitochondria which appear as fat droplets in the preparation stained with oil red are seen to contain small circular regions of formazan deposition. This is not the appearance of normal fat droplets, which are at first colourless, though they may subsequently develop autoxidation products which will reduce adsorbed tetrazolium salts if these are lipid soluble.

\section{Conclusion}

Enzyme histochemistry offers many things, first and foremost, an escape from misleading conceptions due to consideration of tissues as homogeneous. Dixon and Webb (1958), in their masterly work on "Enzymes," say that " it is by no means certain that even cells which are histologically of the same type have the same enzymic composition." In another passage they maintain that "unfortunately no information on the enzymic homogeneity of tissues is available." Enzyme histochemistry, on the other hand, demonstrates with certainty that histologically identical cells frequently have entirely different enzymic composition (examp!es have been given in this paper) and one can say that if " information on the enzymic homogeneity of tissues" is lacking there is already a considerable volume of information on their enzymic lack of homogeneity.

The diaphorase and dehydrogenase methods, a combination of DPNH-diaphorase and succinic dehydrogenase for example, provide a simple and reliable method for demonstrating the mitochondrial population of mammalian, invertebrate, and plant cells. Nobody should further consider for an instant the employment of older staining techniques for these organelles.

Although the true pattern of metabolic activity in cells will only become apparent in most cases when much more exploratory work has been done, one can say, with little exaggeration, that if a single mitochondrion in an organ, or at least in a section from that organ, is abnormal one can demonstrate this fact and determine to some extent the metabolic direction of this abnormality.

Such is the sensitivity of the techniques which I have described that there can be no doubt that probably more than $50 \%$ of all the studies in experimental pathology, carried out by whatever methods since the time of Virchow, can be repeated to-day with advantage and with the absolute certainty that new understanding of "the organization of cellular events" will result. A further application of these techniques can be foreseen in the field of experimental pharmacology where it will be possible to demonstrate the earliest effects of drugs upon cells in sections, smears, or tissue cultures, with obvious economy of effort.

I could wish that Rudolf Virchow were here to-day to describe for himself the possibilities for the extension of his new science of cellular pathology which I have tried, inadequately, to set forth in this article.

It should be evident, from the bibliography, that the results reported in this article are not "all my own work." I should nevertheless like to acknowledge the great help I have received from my colleagues, particularly Drs. Defendi, Grogg, Guerrero, Hess, Macpherson, Pepler, Scarpelli, and Tremblay. 
The photomicrographs are the work of $\mathrm{Mr}$. W. Brackenbury, and the drawings were done by $\mathrm{Mr}$. F. G. Saunders.

\section{REFERENCES}

Allen, J. M., and Slater, J. J. (1956). J. Histochem. Cytochem., 4, 110. Beyer, H., and Pyl, T. (1954). Chem. Ber., 87, 1505

Braun-Falco, O. (1957). Klin. Wschr., 35, 50

Burstone, M. S. (1956). J. nat. Cancer Inst., 16, 1149.

- and Folk, J. E. (1956). J. Histochem. Cytochem., 4, 217. Cameron, G. R., and Muzaffar Hasan, S. (1958). J. Path. Bact., 75 333 .

Cavanagh, J. B., Thompson, R. H. S., and Webster, G. R. (1954). Quart. J. exp. Physiol., 39, 185.

Clayton, B. E., and Hammant, J. E. (1957). J. Endocr., 15, 1.

Coons, A. H., Creech, H. J., and Jones, R. B. (1941). Proc. Soc. exp. Biol. (N.Y.), 47, 200.

Defendi, V., and Pearson, B. (1955). J. Histochem. Cytochem., 3, 61

Dible, J. H., and Gerrard, W. W. (1938). J. Path. Bact., 46, 77.

Dixon, M., and Webb, E. C. (1958). Enzymes. Longmans, London.

Farber, E., and Louviere, C. D. (1956). J. Histochem. Cytochem., 4, 347 .

- Sternberg, W. H., and Dunlap, C. E. (1956a). Ibid., 4, 254.

- (1956b). Ibid., 4, 284.

Fishman, W. H. and Baker, J. R. (1956). Ibid., 4, 570

Glick, D., and Nayyar, S. M. (1956). Ibid., 4, 389.

Gomori, G. (1939). Proc. Soc. exp. Biol. (N.Y.), 42, 23.

Goormaghtigh, N. (1939). Brux.-med., 19, 1541 .

Green, M. H., and Verney, E. L. (1956). J. Histochem. Cytochem., 4,106

Grogg, E., and Pearse, A. G. E. (1952). Brit. J. exp. Path., 33, 567.

Hess, R., and Pearse, A. G. E. (1959). J. exp. Med. In the press.

Scarpelli, D. G., and Pearse, A. G. E. (1958). Nature (Lond.), 181, 1531 .

Holt, S. J. (1952). Ibid., 169, 271.

and Withers, R. F. J. (1952). Ibid., 170, 1012

(1958). Proc. roy. Soc. B., 148, 520.
Koelle, G. B. (1954). J. comp. Neurol., 100, 211.

Monis, B., and Rutenberg, A. M. (1956). J. Histochem. Cytochem., 4, 498.

Nachlas, M. M. Crawford, D. T., and Seligman, A. M. (1957) Ibid., 5, 264

- Tsou, K.-C., de Souza, E., Cheng, C.-S., and Seligman, A. M. (1957). Ibid., 5, 420.

Walker, D. G., and Seligman, A. M. (1958). J. biophys. biochem. Cytol., 4, 29

Novikoff, A. B. (1955). In Analytical Cytology, ed. R. C. Mellors, McGraw-Hill, New York.

- (1956). Proc. 3rd int. Congr. Biochemistry, Brussels, 1955. p. 315. Academic Press, New York.

Pearse, A. G. E. (1957). J. Histo hem. Cytochem. 5, 515.

(1959). Histochemistry, Theoretical and Applied, 2nd ed. J. \& A Churchill, London. In the press.

and Macpherson, C. R. (1958). J. Path. Bact. 75, 69

and Pepler, W. J. (1957). Nature (Lond.), 179, 589.

and Scarpelli, D. G. (1958). Itid., 181, 702 .

and Tremblay, G. (1958). Ibid., 181, 1532.

Pepler, W. J., and Pearse, A. G. E. (1957). J. Neurochem. 1, 193.

Ruienburg, A. M., Gofstein, R., and Seligman, A. M. (1950). Cancer Res., 10, 113.

Scarpelli, D. G., and von Haam, E. (1957). Amer. J. Path., 33, 1059. Hess, R., and Pearse, A. G. E. (1958). J. biophys. biochem Cytol, 4.

Schneider, W. C. (1956). Proc. 3rd int . Congr. Biochemistry. Brussels, 1955, p. 305. Academic Press, New York.

Seligman, A. M. and Rutenburg, A. M. (1951). Science, 113, 317.

Sternberg, W. H., Farber, E., and Dunlap, C. F. (1956). J. Histochem Cytochem., 4, 266.

Sylvén, B., and Malmgren, H. (1955). Exp. Cell Res., 8, 575.

Tremblay, G., and Pearse, A. G. E. (1959). Brit. J. exp. Path. In the press.

Tsou, K.-C., Cheng, C.-S., Nachlas, M. M., and Seligman. A. M. (1956). J. Amer. chem. Soc., 78, 6139.

Virchow, R. (1858). Cellular Pathology (English translation by $F$ Chance, 1860). Churchill, London.

Woodard, H. Q. (1952). Cancer, 5, 236.

Young, J. Z. (1956). Endeavour, 15, 5. 